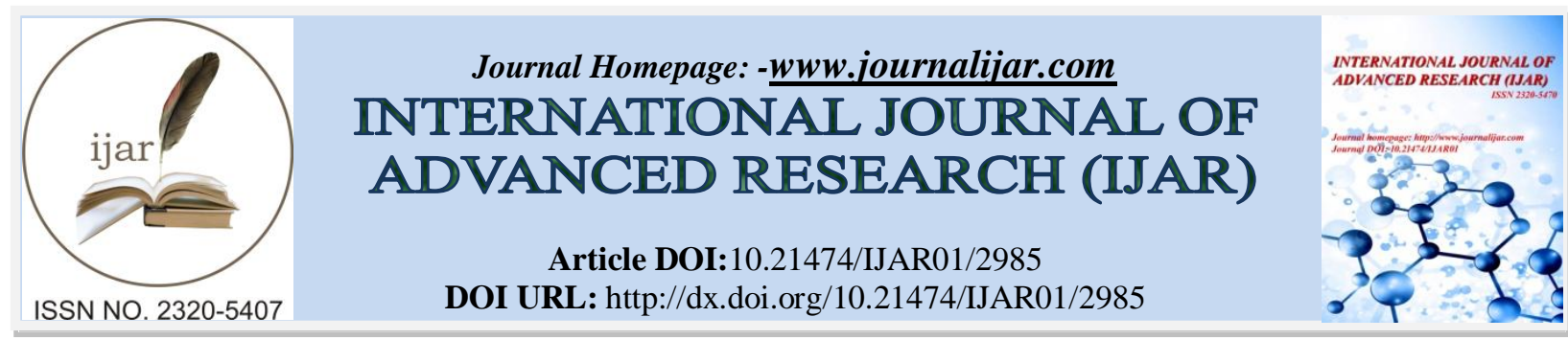

RESEARCH ARTICLE

\title{
MAIN PREDICTORS ON THE USE OF BIOMATERIALS IN IMPLANT DENTISTRY: A REVIEW
}

Yeda Duarte de Souza Rodrigues ${ }^{1}$, Matheus Furquim Ruis ${ }^{1}$, Larissa Francisco Inacio ${ }^{1}$, Regis Manzini' ${ }^{2}$, Wesley Antonio Galhardo Fornazari ${ }^{2}$, Carlos Alberto Costa Neves Buchala, ${ }^{1,2}$, Ana Paula Bernardes da Rosa Maluf Abbud $^{1,2}$, TaylaneSoffenerBerlanga de Araúji ${ }^{1,2}$, Elias Naim Kassis ${ }^{1,2}$ and Idiberto Jose Zotarelli Filho $^{2}$

1. University Center North Paulista (Unorp) - São José do Rio Preto - SP, Brazil.

2. Post graduateandcontinuingeducation (Unipos), Street Ipiranga, 3460, São José do Rio Preto SP, Brazil 15020040 .

\section{Manuscript Info}

[........................

Manuscript History

Received: 28 November 2016

Final Accepted: 27 December 2016

Published: January 2017

Key words:-

"Implantology","Regenerative Surgery",

"Biomembranes", "Bioengineering Bone".

\section{Abstract}

Over the past 30 years, the number of dental implant procedures has been increasing worldwide, reaching about one million dental implants per year. In Brazil, in the last decades, there has been a very rapid evolution in implant dentistry with high success rates. The development of biomaterials for use in dental clinics in recent years has represented a powerful therapeutic tool in the correction of bone defects. This study aims to analyze and discuss the main types of biological membranes, positives, negatives, their indications and results. For the development of the present revision work, we used a database such as Medline, Embase, Pubmed, Ovid and Cochrane. The main descriptors (MeshTerms) used were "Implantology", "Regenerative Surgery", "Biomembranes", "Bioengineering Bone". Based on the literary findings, both non-absorbable and absorbable membranes are effective in the process of bone regeneration. Absorbents do not require a second surgical time. However, there are information gaps, and further research is needed to ensure the perfect knowledge of the properties of the physical barriers to achieve a perfect bone regeneration of the periodontal bone defects and around implants. Due to bone regeneration and biological barriers in the Grafting surgeries, there was a technological growth of these materials because they pointed out as potential tools for the treatment of bone loss.

Copy Right, IJAR, 2016,. All rights reserved.

\section{Introduction:-}

In the last 30 years, the number of dental implant procedures has been increasing worldwide, reaching about one million dental implants per year [1,2]. In Brazil, in the last decades, there has been a very rapid evolution in the Implantodontia with high success rates [3]. The development of biomaterials for use in dental clinics in recent years has represented a powerful therapeutic tool in the correction of bone defects [3]. However, in spite of proven benefits, its use requires the professional to take clinical and ethical care in the analysis of the risks and benefits that each biomaterial can present.

Corresponding Author:- Prof. Dr. Idiberto José Zotarelli Filho. 
A study of 123 dental surgeons using biomaterials showed that professionals are not aware of the risks and benefits of biomaterials, nor of their biological principles, since $45 \%$ believe there is no risk to the patient and $56 \%$ do not consider Biomaterial as medicine. About $70 \%$ felt secure with respect to the origin [3]. Despite this, $96 \%$ of respondents said that there should be greater control of health authorities. More than half of the interviewees (51\%) reported little or no patient participation in the process of therapeutic choice [3].

Many patients, elderly or not, sought implant-supported rehabilitation, but there is a need for some adjustments that lead to the consequent demand for regenerative procedures for maxillary reconstructions [5]. These patients can often present pathological changes, or make use of medications, which may alter bone healing [5]. Several materials can be used as a bone graft, each with different properties; For example: for neovascularization, materials such as hydroxyapatite and calcium phosphate showed the highest expression rates of vascular growth factors (VEGF) and microvascular density; While the polymer grafts showed the lowest rates [8].

The search for a solution for large bone defects has begun studies based on guided tissue regeneration therapy or guided bone regeneration. These studies promote the use of fillers and epithelial barriers that aid in treatment as an adjunct to bone grafting techniques. Thus, they favor greater predictability in alveolar and peri-implant reconstructions and present a good prognosis [4].

The main problem is with non-absorbable membranes, because they require a second surgical act, they provide infections if there is any type of exposure; Have a consistent consistency, which makes it difficult to adapt to the bone defect and thus impairs blood supply and can cause dehiscence and tissue necrosis [5-7].

Guided bone regeneration (GBR) favors the formation of new bone tissue and prevents the gingival tissue from invaginating into the space between the bone and the implant [5,6]. Covaniet al [9] in a prospective 10-year study comparing patients who received the GBR technique with patients who did not receive indicated the possibility of gingival retraction in the group that did not receive the technique when compared to the group that received [4].

The filling materials can be: hydroxyapatite, lyophilized and milled demineralized bone marrow, autogenous bone, which is considered gold standard, among others. In conjunction with fillers, it is often necessary to use features to isolate the implant by using biological membranes, which are epithelial barriers that guide tissue regeneration, function as a mechanical barrier separating the periodontal tissues from the Bone surface or implant, thus promoting a new bone formation, a containment of the filling material and a stability of the graft $[6,8]$.

This study aims to analyze and discuss the main types of biological membranes, positives, negatives, their indications and results.

\section{Methods:-}

For the development of the present review, we used a database such as Medline, Embase, Pubmed, Ovid and Cochrane (figure 1). The main descriptors (MeshTerms) used were "Implantology", "Regenerative Surgery", "Biomembranes", "Bioengineering Bone" (Table 1).

\section{Main Continuous Predictors:-}

The main continuous predictors were the inflammatory processes and the chemical quality of the biomembranes.

\section{Main Preditor Answer:-}

The main predictor response was massive bone regeneration.

\section{Literary Review:-}

Epidemiology and Justification:-

According to data from the Brazilian organ transplant association, the number of bone transplants per million population reaches 450 (18,200 transplants) in the State of São Paulo, 110 (4,100 transplants) in the State of Paraná and 30 (1,200 transplants) in the State of Rio de Janeiro, made available by the 5 Tissue Banks of the 3 States, during the $10^{\text {th }}$ quarter of 2012 [13]. 
The lack of bone in the alveolar ridges has been a major problem in functional aesthetic recovery in patients who have suffered dento-alveolar trauma, traumatic dental extractions, congenital dental absence, pathologies involving maxilla and mandible, as well as infections due to the emotional and Possibility of deformity and also the economic impact they cause in the National Health System (NHS) [11,13]. Bone loss can also occur due to periodontal disease, traumatic surgeries, or even for physiological reasons due to lack of adequate bite function or prosthetic load [14].The trauma in the face region can reach both the soft tissues (skin, muscles, nerves) and hard tissues (bones, teeth), so these lesions can affect the quality of life as well as the health of the victim [14].

The trauma maxillofacial injury can be considered one of the most devastating aggressions found in traumatology and oncology, due to the emotional consequences and the possibility of deformity and also the economic impact they cause in the National Health System (NHS) [15- 18]. The face, more than any other region of the body, is affected by aesthetic changes, since it is always visible, and damages are perceived immediately [19]. For this reason the trauma of the face deserves attention in the treatment of polytrauma due to its high incidence and severity.

\section{Tissue Engineering:-}

The microscopic bone structure consists of osteoprogenitor cells, support cells (osteoblasts and osteocytes), remodeling cells - osteoclasts - and a non-mineralized extracellular matrix called the osteoid, composed of type I collagen and non-collagen proteins such as osteonectin, osteocalcin, Morphonetic bone protein (BMP), glycosaminoglycans (GAG) and bone sialoproteins [29]. The osteoprogenitor cells are small spindle cells found on all non-resorbable bone surfaces, derived from primitive mesenchymal cells and form a population and precursor cells that can differentiate into more specialized cells such as osteoblasts and osteocytes [15].

Regeneration of composite tissues such as periodontal tissue has also been demonstrated, proving that adipose stem cell associated with platelet rich plasma can regenerate alveolar bone, cementum and periodontal ligament eight weeks after implantation [22,23]. Clinically, there is a combined study of bone graft with fibrin glue, a biodegradable biomaterial and adipose stem cell for the reconstruction of extensive bony defect in the skull cap of a 7-year-old victim of trauma [22].

Osteoblasts are derived from undifferentiated stem-cells and are responsible for the production of bone matrix, rich in collagen (mainly type I) and essential for subsequent mineralization, by adherence of calcium hydroxyapatite crystals, magnesium, potassium, sodium and Carbonate in collagen fibrils [10,20]. Osteoblasts are also rich in alkaline phosphatase, which has a high value in periods of bone formation. The process of formation of new bone mediated by osteoblasts is called osteogenesis [10]. It is known that osteoblasts bind directly to collagen through integrin-RDG (-Arg-Gly-Asp-) sites of interaction.

The osteoinduction process is influenced by several factors and consists in the induction of mesenchymal stem cells of adipose tissue in osteoprogenitor cells $[15,25]$. Osteogenic differentiation requires the presence of inducers, which include $\beta$-glycerolphosphate, ascorbic acid and dexamethasone [25]. In the presence of these substances the mesenchymal cells acquire the morphology and components of osteoblast membranes and begin to express alkaline phosphatase, to deposit extracellular matrix rich in calcium and certain proteins, such as osteopontin and osteocalcin [25].

Organic phosphates, such as $\beta$-glycerolphosphate, promote osteogeny by their function in mineralization and modulation of osteoblast activity [15]. Thus, free phosphates can induce mRNA and protein expression, exemplified by the osteopontin protein. If organic phosphate, for example $\beta$-glycerolphosphate is present, the formation of a mineral content occurs, hydroxyapatite that is formed between the collagen fibers [21]. Other compounds such as phosphoric ascorbic acid are also used in osteogenic induction, in the involvement of increased alkaline phosphatase activity and in the promotion of the production of osteocalcin and osteopontin [25,27].

Bone morphogenetic proteins (BMPs) function as growth factors with a specific role in the proliferation and differentiation of mesenchymal stem cells from adipose tissue [17,24]. BMP-4 is involved in the early stages of osteogenesis; in addition, it has been shown that the differentiation of human adipose mesenchymal stem cells into the osteogenic lineage requires the presence of BMP-4 in the first days of culture and that these cells, after 21 Days express specific proteins of the osteogenic lineage such as osteonectin, osteocalcin and osteopontin [24]. There are three fundamental parameters in bone tissue engineering that will determine the ability of osteoinduction are the 
presence of soluble osteoinductive signals, the viability of the undifferentiated mesenchymal stem cells to respond, the ability to differentiate into bone-forming cells and the production of extracellular matrix Adequate [24].

Tissue engineering encompasses numerous advantages that meet the needs of injured tissue or organ for the regeneration process [12,17]. For this, it is necessary the understanding of chemical, physical and biological processes both biological material and the biological niche of the host [13]. The cross-referencing of compatible information between the microenvironments allows cellular recognition and signaling cascades for neovascularizations [14]. Another advantage is minimally invasive surgical intervention, that is, it allows the use of surgical techniques that are faster and cause less risk to the patient [19].

Thus, tissue engineering is a tool that makes possible through a suitable biological niche the construction and regeneration of any tissues and organs [18,27]. For this, xenografts, autografts and allografts are used, with and without the use of cells $[13,14]$. According to the Conference of the National Institute for the Development of Health Consensus in 1982, biomaterials are beneficial organic compounds, or a combination thereof, that can be used for a period of time, wholly or partially as part of a system that treats, Replace any tissue, organ or function of the human body $[18,27,30]$.

The great challenge is to understand that the science of biomaterials is multidisciplinary and its application requires adjustments of its processing, sterilization and structural modifications to favor the interaction with the tissue of interest.Bioengineering and cell therapy work together for Regenerative Medicine, favoring and improving biological conditions to accelerate repair and tissue regeneration, and thus naturally maintaining tissue homeostasis [16]. This condition is maintained because the required cellular elements, cell proliferation and differentiation factors, and supramolecular structures are provided which guarantee the functional stereochemical organization of the tissues generated and their systemic integration $[18,27,30]$.

\section{Biomaterials:-}

It is used to direct, through the control of interactions with components of a living system, the course of a diagnostic or therapeutic procedure, whether in humans or animals. Checking the history of biomaterials in the medical-dental area, countless researches have been carried out in the search for natural or synthetic substances that can replace lost, hard or hard bodied tissues [31].

Thus, ancient records show us the use of substances, such as ivory. Dry bone, gold, gold wire, silver alloys, among other materials. From 1800, it is observed the use of synthetic compounds for bone replacement, when researchers advocated the use of calcium sulfate in bone defects [31].

Due to the great technological development of biomaterials, associated with the advancement of knowledge about the biology of bone tissues, it has become possible to selectively influence bone formation, controlling the quality and quantity of bone inside the buccal structures [31].

In this way, there is a wide variety of biomaterials, synthetic or biological, with variable particle sizes and mainly classified according to their mode of action: osteoconduction, osteoinduction or osteogenesis. In implantology, implant placement should be used as complementary therapy, and it is necessary to know the biological potential of each material to indicate it in the various clinical situations [31].

We can find in the market a varied range of biomaterials, such as demineralized lyophilized bone, anorganic bone and bioactive glass. These biomaterials should have precise indications and should not require unreal biological demands from them. It is known that bone neoformation is a biological process that happens at the expense of osteoblastic activity and that the quality of the neoformed tissue, when in the presence of these biomaterials, is not the same for all, and depends on the material, its origin, clinical conditions The recipient site, the field of indications and the surgical technique [31].

\section{Maintenance OfAlveolus Size After Exodontia:-}

The concern of the implantant after the extraction, is the bone loss in volume of the alveolus [31-33]. When it is not possible to install immediate implants, after exodontia, the alveolar process, depending on the thickness of the buccal bone board at the end of the bone remodeling process, may present depression on the vestibular surface, which would imply the need for block autogenous graft [33]. 
In a study carried out in 1967, it was observed that in the anterior maxilla there is loss of $25 \%$ of bone volume in the first year after exodontia. In the posterior region it is twice as large as in the anterior maxilla [34].

It is believed that if the bone defect is five walls (alveoli with intact walls) the alveolar bone repair will happen naturally. However, if the vestibular wall is less than $1.5 \mathrm{~mm}$ thick or absent, the practitioner should use intraalveolar materials (autogenous bone, mineralized bone or alloplastic material), associated with membranes that improve the predictability of Restoration of the original bone contour in the alveolar process [35]. There is an indication of the technique called Bio-col for preservation of alveolar bone walls.

The author uses Bio-oss (inorganic material of bovine origin) as osteoconductive material that according to the author's understanding is slowly reabsorbed and replaced with vital bone [18].If the bone defect is more than $2 / 3$ of the vestibular wall, the reconstruction should be done with autogenous bone. Authors evaluated the action of two types of bioactive glass particles on mandibular alveoli after exodontia in dogs, and concluded that both Biogran and Biossilicate preserve the alveolar bone height and enable the implantation of implants [36].

Regarding the use of bone-guided regeneration, a study confirmed bone ridges after exodontia with and without the use of biological membranes. After six months, bone crest loss of $0.38 \mathrm{~mm}$ versus $1.50 \mathrm{~mm}$ and horizontal bead reabsorption of $1.31 \mathrm{~mm}$ versus $4.56 \mathrm{~mm}$ respectively were observed.

For a better predictability of the guided bone regeneration technique there is a requirement that the membrane be totally protected by the mucoperiosteal flap and that, in the presence of teeth, it is at least $1 \mathrm{~mm}$ away from the periodontal space [37].It is also necessary that the biological space be maintained by membrane memory, or that the membrane be supported by the interdental septal bone structure, or by the remainder of the alveolar bone walls. If this condition does not exist, autogenous particulate bone, mineralized or synthetic biomaterial can be used [38].

In bone defects of four walls the indication of reconstruction falls on the autogenous bone or mineralized bone with membrane. Using the technique, which seals the alveolus with tissue composed of mucosa and trabecular bone obtained from the tuft of the maxilla with the aid of trephine drill of 6.0 to $10.0 \mathrm{~mm}$ in diameter [39].

On the other hand, bone defects with two or three walls require that the biomaterial to be used to reconstruct be the autogenous bone combined with the use of biological membranes [39]. On the other hand, the bone defect of a wall requires block grafting with fixation by means of screws. Based on the work of several authors, the implantation of implants in reconstructed areas with any biomaterial should be 4 to 6 months [39].

\section{Border Outline:-}

There are cases where the remaining bone tissue is sufficient to stabilize the implant, but there is deficiency of vestibular border contour that causes at the time of implant installation, partial dehiscence of the buccal bone board. Biomaterials are used to improve the contour of the collar, consequently the harmony of the prosthesis [31-33].

Biomaterials most suitable for improving the border contour are the inorganic ones, which maintain the volume and are not reabsorbed. When using these biomaterials, biological membranes should be used to protect the area and prevent biomaterial detachment [34-36].

The incorporation of the material into the receptor bed and stabilization of the material by fibrosis or adjacent soft tissue is observed. There can be no exposure of the biomaterial to the oral environment. This would cause its contamination and the failure of the surgical procedure [36,37].

It is also possible to use particulate autogenous bone, being biologically more favorable, the area should be well selected presenting thick and keratinized gingival tissue. At the moment of implant opening, part of the material is seen next to the gingival tissue and part forming a mass adhered to the bone [38].

\section{Peri-implant Bone Defect Filling:-}

Authors conducted a histological study in humans and concluded that the spontaneous repair of the peri-implant defect occurs when the space between the implant and the bone wall is up to $2.0 \mathrm{~mm}$. $25 \%$ of sites with gaps greater than $2.0 \mathrm{~mm}$ were found to be repaired compared to $78 \%$ of gaps less than $2.0 \mathrm{~mm}$ [34]. 
Peri-implant bone defects in implants immediately after extraction, less than $2.0 \mathrm{~mm}$, do not need to be filled, because spontaneous repair will occur. However, if the gap is greater than $2.0 \mathrm{~mm}$, space filling should be performed in association with biological membranes [35]. In this case, the biomaterials in the form of particles are trapped by the bone walls, making use of either demineralized, mineralized materials, bioactive glass or particulate autogenous bone.

It is intended to fill the space by neoformed bone, and for this reason, the material used must have osteoconductive properties; To avoid the peri-implant bone defect, which is more worrying in the anterior maxilla region, due to aesthetics; Preserving the height of the alveolar process, including the interdental septa and raising the maxillary sinus membrane, or sinus graft [38].

\section{Increase In Height And / Or Thickness Of The Alveolar Process:-}

Autogenous block-shaped bone is indicated for the use of homogeneous, heterogeneous or haloplastic materials. The most used donor areas are: iliac crest, skull cap, chin, or oblique line. It is suggested that for total reconstructions, the most indicated would be: iliac crest and skull cap. When the reconstruction encompasses height and thickness, simultaneously, the iliac crest is the most indicated [31].

For reconstruction in thickness, the skull cap is more advantageous because there is little remodeling of the graft during the period of repair; Because bone quality is more adequate for implant installation; By the preoperative period have the minimum of symptomatology and for the shortest period of hospitalization.

For partial reconstructions, with individual losses or two dental elements, the oblique line can be indicated and, in loss of up to four elements, the ment would be more adequate indication [31].

\section{Elevation OfMaxillary Sinus:-}

The maxillary sinus survey, using bone grafts, became one of the most frequent procedures of implantology and also the most investigated by the use of platelet concentrates. Another reason is that it is a good model of evaluation of bone remodeling and is a closed and protected cavity where the interferences with the oral environment are minimal $[29,30]$.

Many studies have reported that the addition of platelet rich plasma to a bone graft is associated with positive clinical results and is a good method of handling the bone graft during insertion in the maxillary sinuses and stimulates bone regeneration around implants placed in the graft. However, it is difficult to emphasize the conclusions of the studies carried out due to the large variables present in the in vivo models, however, in general the authors affirm that the quality of the bone formed and that the surgical technique used does not present advantages in the therapy $[29,30]$.

\section{Guided Bone Regeneration And Guided Tissue Regeneration:-}

Guided bone regeneration is the technique that uses osteopromotion as a biological principle. It is indicated for bone regeneration in fresh alveoli, bone defects that have remaining bone walls, to promote bone neoformation around implants installed immediately after extraction, to correct bone loss (Peri-implant) that occurred after osseointegration [31].

It is used for correction of defects, when it is desired, increase of bone volume, for this it is necessary, that the tissue recomposes cells with characteristics of the region without interference of the connective tissue [32]. Guided tissue regeneration promotes selective cellular response without producing an inflammatory reaction. Its use presents a degree of specificity to the type of tissue where it will be performed [32].

\section{Important Features OfThe Biological Membrane For Bone Neoform:-}

It should function as a physical support to the surrounding soft tissue, preventing the collapse of this space that will be filled by the blood clot, necessary for bone formation. It should also possess permeability that allows diffusion of plasma and nutrients, but which prevents the passage of non-osteogenic cells, in addition to having biocompatibility integration with the host tissue without creating inflammatory responses [32]. 
The first membranes to be successfully used in bone regeneration were expanded polytetrafluoroethylene, nonresorbable. The eventuality of exposure posed a risk of infection, requiring premature removal. Due to this inconvenience they developed resorbable membranes, collagen or polylactic acid polymers [32].

\section{Membrane Characteristics:-}

They must have good tissue integration, ensuring the growth of cells without crossing the material; Prevent the early migration of the epithelium on the outer surface of the material or encapsulation of the material; To provide stability to the suprajacent retail; Be available in easy configuration for better adaptation; Present selectivity (passage of nutrients, gases) and have occlusive property. The right choice of membrane to take advantage of its basic characteristics will depend on the operator's ability and his mastery with the material [32].

\section{General Characteristics Of Indications For Each Thickness:-}

Fine membranes are used when the need is only for insulation of the site. Medium membranes are used for insulation, and should have greater or lesser degree of strength and stiffness according to the imposed deformation. Thick membranes confer structural action, creating ample space and sustaining in adverse conditions.

\section{Non-Absorbable Membranes:-}

They are formed by overlapping layers of Teflon, of highly ordered structure, giving a controlled porosity that allows passage of liquids. They consist of two parts, a peripheral part of greater porosity and flexibility, which guarantees the adaptation to the margins of the bone defects and another part of less permeability with greater rigidity.

The disadvantages of non-absorbable membranes are the need for additional surgical intervention for their removal and possible complications associated with membrane exposure, leading to infections, requiring removal and disruption of the regenerative process [32].

Expanded polytetrafluoroethylene membranes do not trigger inflammatory reaction, foreign body, has autoclave resistance, insoluble to a range of enzymatic solvents, has elasticity similar to bone tissue. It is reinforced with titanium and indicated for situations in which the formation of bone with great defects is desired.

They are composed of double layer polytetrafluoroethylene expanded with titanium interposed. These barriers incorporate into their structure a skeleton, formed by a thin titanium blade. Titanium membranes are capable of promoting the formation of significant amount of new bone and maintaining sufficient space without the use of a support device [32].

\section{Reaborvable Membranes;-}

Reabsorbable membranes eliminate the need for additional surgery. They are classified in: natural and synthetic. They are degraded by the body through enzymatic hydrolysis, triggered by the inflammatory infiltrate that forms around the material.Collagen-based membranes are widely used today. Its efficacy is demonstrated by studies, however there is disagreement as to its use. They have their origin: bovine, swine and derived from the dura mater of the human brain, collected and submitted to the lyophilization process to eliminate antigenic substances. Before its positioning, it must be hydrated by immersion of the membrane in saline.

The resorbable membranes, diverts the body's attention to a process, which is its own removal from the site. Alumina is an alloplastic membrane that presents characteristics of passivity in the scarring process, makes isolation, spacing and stabilization, and does not generate any mechanism capable of altering the process.

The autogenous graft is considered the best because it guarantees predictable results, due to the lower rejection rate. Due to this, when coated with membrane, the autogenous bone can reach $50 \%$ of the original bone volume in up to six months.Bovine bone, when associated with non-absorbable membranes, begins the resorption process from the seventh month, and has a significant effect on bone filling parameters after a period of nine months [32].

\section{Discussion:-}

Based on the literary findings, both non-absorbable and absorbable membranes are effective in the process of bone regeneration. Absorbents do not require a second surgical time [33,34]. However, there are information gaps, and 
further research is needed to ensure a perfect knowledge of the physical barrier properties to achieve a perfect bone regeneration of the periodontal bone defects and around implants [34,35,36].

In this context, the use of biomaterials and membranes contribute to an optimized outcome in the rehabilitations with osseointegrable implants. Another prospective 3-year study in patients receiving platform switching implants indicated predictability of the technique associated with guided bone regeneration for aesthetic area reconstruction [34]. In a 10-year longitudinal prospective study, they indicated the possibility of gingival retraction in a group of patients who did not receive guided bone regeneration when compared to a group of patients who received the guided bone regeneration technique.

Regarding the use of the biomaterial, clinical studies have indicated predictability of the technique [34,35]. Another study showed in a randomized controlled clinical study that the guided bone regeneration technique using different biomaterials (Bone Ceramic / Bio-Oss) presented predictability and that both materials are suitable for preserving width and interproximal bone height of the collar Alveolar [18,28].

Another important aspect is the creation of a provisional implanted implant, since this prosthesis presents several functions such as adaptation of the patient, choice of color and shape, allowing gingival conditioning that besides obtaining aesthetics, such conduct represents less clinical time to the prosthetist During the final restoration phase [34-36].

In addition, gingival conditioning allows the adjacent soft tissues to be directed during the osseointegration phase, thus avoiding gingival targeting maneuvers for esthetics [33]. The use of biomaterials in dentistry occurs on an increasingly wide scale. Several studies have demonstrated the synthesis of new biomaterials applied in all areas of dentistry with promising results [33-35].

Thus, the use of biomaterials at a clinical level should essentially be analyzed through the entire scientific evaluation process, ranging from in vitro laboratory tests to longitudinal clinical studies in vivo. Thus, the development of bioceramics and prostheses constituted by these materials must occur under the same interdisciplinary conditions that determine the development of any other dental material [19].

In addition, there is a need to know all the properties mentioned here by the Dentist, so that there is a critical discussion about the use of biomaterials, avoiding only commercial information that is often incomplete and superficial $[19,34]$. The opportunity to discuss the use of biomaterials in dentistry, through the science of dental materials, expands the knowledge of this subject for professionals and researchers [19].

The diversity of applications of biomaterials, as well as their chemical, physical, biological and morphological differences, makes the research in this area of knowledge a work with eminently interdisciplinary characteristics. Within this context, professionals in the field of Materials Engineering can contribute significantly to the evolution of this area and to increase the range of its applicability, through the development of new and effective biomaterials and also in the elucidation of the mechanisms that govern the Bone regeneration [34-37]. 
Figure1.Quantification as a percentage of the recent papers published in the mentioned journals, broken down by meta-analysis and decision analysis.

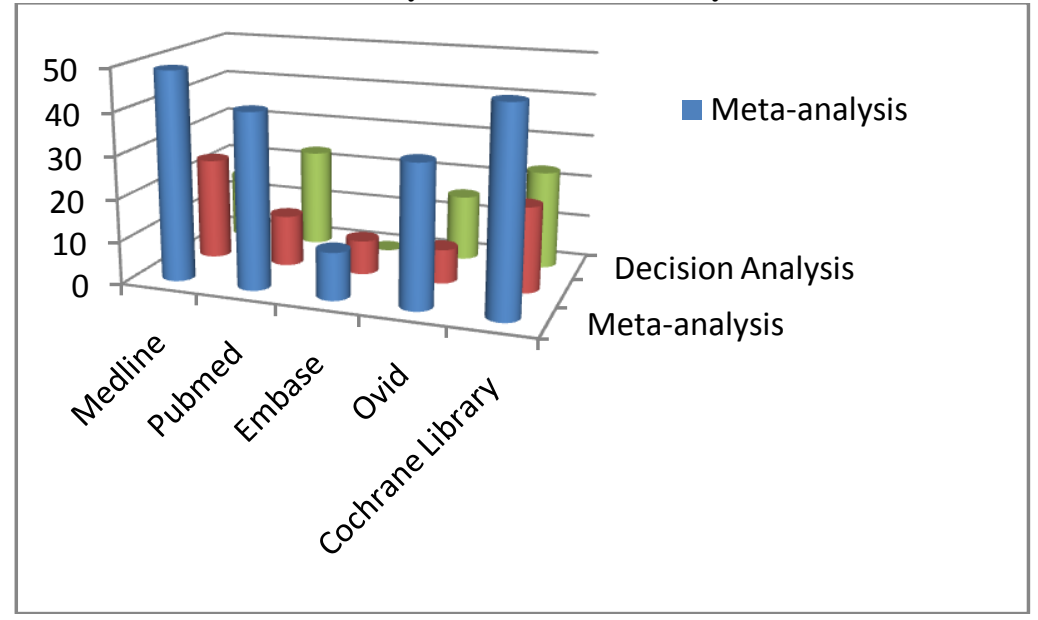

Table 1. Main current references and outcomes on the use of biomembranes

\begin{tabular}{|l|l|}
\hline \multicolumn{1}{|c|}{ AUTHOR } & \multicolumn{1}{c|}{ OUTCOMES } \\
\hline $\begin{array}{l}\text { Caballé-Serrano et al. } \\
(2015)[33]\end{array}$ & $\begin{array}{l}\text { The protocols presented should encourage further revealing the paracrine effects of } \\
\text { bone grafts during bone regeneration and pave the way for translational research in } \\
\text { the broad field of reconstructive surgery. }\end{array}$ \\
\hline $\begin{array}{l}\text { Merli Met al. } \\
(2016) \text { [34] }\end{array}$ & $\begin{array}{l}\text { No substantial differences were obtained using different membranes and non- } \\
\text { resorbable grafts, and the results were positive for the variables examined. A result } \\
\text { of high heterogeneity has been observed in studies related to cross-linked } \\
\text { membranes. }\end{array}$ \\
\hline $\begin{array}{l}\text { Moschouris Pet al. } \\
(2016) \text { [35] }\end{array}$ & $\begin{array}{l}\text { The recombinant protein Wnt3a in conjunction with GBR tissue can promote bone } \\
\text { formation. }\end{array}$ \\
\hline $\begin{array}{l}\text { Caballé-Serrano } \\
(2016) \text { [36] }\end{array}$ & $\begin{array}{l}\text { These results demonstrated that collagen membranes can rapidly absorb the activity } \\
\text { of TGF- } \beta \text { released from bone splinters, a molecular process that may contribute to } \\
\text { guided bone regeneration. }\end{array}$ \\
\hline $\begin{array}{l}\text { Saghiri MA et al. } \\
\text { (2016) [37] }\end{array}$ & $\begin{array}{l}\text { Angiogenesis is one of the key factors that plays a critical role in the success rate of } \\
\text { the GBR technique and is seriously considered in the manufacture of bone and graft } \\
\text { membrane barrier materials. However, there is still a lack of clinical and in vivo } \\
\text { studies on the effect of angiogenesis on bone and graft treatments of barrier } \\
\text { membrane materials. }\end{array}$ \\
\hline $\begin{array}{l}\text { Fujioka-Kobayashi M et al. } \\
\text { (2016) [38] }\end{array}$ & $\begin{array}{l}\text { The results indicate that the combination of collagen membranes with rhBMP9 } \\
\text { significantly induced significantly higher mRNA expression and alizarin alizarin red } \\
\text { staining when compared to rhBMP2. These findings suggest that rhBMP9 may be a } \\
\text { suitable growth factor for future regenerative processes in bone biology. }\end{array}$ \\
\hline $\begin{array}{l}\text { Dai Z, Shu Y, Wan C, Wu } \\
\text { C(2015) [39] }\end{array}$ & $\begin{array}{l}\text { These microgels provided an extracellular matrix microenvironment that affect the } \\
\text { biological behavior of mesenchymal stem cells, facilitating their potential } \\
\text { applications in regenerative bone therapies. }\end{array}$ \\
\hline
\end{tabular}

\section{Conclusion:-}

Because of bone regeneration and biological barriers in graft surgeries, there has been a technological growth of these materials because they are pointed as potential tools for the treatment of bone loss. Therefore, for its ethical and safe use, it is necessary for the professional to be careful in its use by assessing the advantages and disadvantages by means of prospective and randomized clinical studies of each material and with high casuistics. 


\section{References:-}

1. Pye AD, Lockhart DEA, Dawson MP, Murray CA, Smith AJ. A review of dental implants and infection. J HospInfect ; 2009, 72:104-110.

2. Branemark PI, Hansson BO, Adell R, Breine U, Lindstrom J, Hallen O et al (1977) Osseointegrated implants in the treatment of edentulous jaw. Experience from a 10-year period. ScandJPlastReconstrSurgSuppl 16:1-192.

3. BugarinJúniorJG,GarrafaII V. Bioethics and biosafety: the use of biomaterials in dental practice. Rev SaúdePública 2007;41(2):223-8.

4. Mazaro JVQ, Godoy PAI, Junior JFS, Mello CC, Pellizzer EP, ZavanelliAC ; Regeneração óssea guiada em implantodontia: relato de caso ; RFO, Passo Fundo, v. 19, n. 1, p. 121-128, jan./abr. 2014.

5. BusettiJ ; Avaliação histológica e histomorfométrica da regeneração óssea guiada sob membranad]s biológicas não reabsorvíveis em ratas osteoporóticas com e sem tratamento com ácido zoledrônico ; Porto Alegre, 2015.

6. Fernandes TBG. Utilização de membranas absorvíveis e não absorvíveis em técnicas de regeneração óssea na implantodontia ; Uberlândia, 2015.

7. Costa JBZ, Silva F, Dultra CA, Souza LF, Santos MCNE ; Uso de membranas biológicas para regeneração óssea guiada em implantodontia - uma revisão de literatura - Revista Bahiana de Odontologia. 2016 Mar;7(1):14-21.

8. Saghiri MA, Asatourian A, Garcia-Godoy F, Sheibani N. The role of angiogenesis in implant dentistry part II: The effect of bone-grafting and barrier membrane materials on angiogenesis. Med Oral Patol Oral Cir Bucal. (2016), doi:10.4317/medoral.21200.

9. Covani U, Chiappe G, Bosco M, Orlando B, Quaranta A, Barone A. A 10-year evaluation of implants placed in fresh extraction sockets: a prospective cohort study. J Periodontol 2012; 83(10):1226-34.

10. Calasans MD., Fernandes GVO.; Granjeiro, JM. Preservação alveolar com enxertos após exodontias e previamente à instalação de implantes. RevistaImplantnews, 2011, 6: 583-590.

11. Fontanari LA; Manne JM; Junior WT. Utilização de enxerto homógenos para reconstrução em áreas atróficas pré-implante: banco de ossos. RevistaImplantnews, 2007, 5 (6) : 539-597.

12. Gimble JM.; Katz AJ.; Bunnell BA. Adipose-Derived Stem Cells for Regenerative Medicine. Circ Res; 2013, 100:1249-1260.

13. Hallman M, Cederlund A, Lindskog S, Lundgren S, Sennerby L. A clinical histologic study of bovine hydroxyapatite in combination with autogenous bone and fibrin glue for maxillary sinus floor augmentation. Results after 6 to 8 months of healing. Clin Oral Implants Res 2001 Apr;12(2):135-143.

14. Hing K. A. Bone repair in the twenty-first century: biology, chemistry or engineering? Philos. Trans. R. Soc. Lond. B. Biol Sci., 2004, 362( 1825) : 2821-2850.

15. Langer R. ;Vacanti JP. Tissue Engineering. Science 1993; 260 : 920-926.

16. Lima, A F.; Martorelli. Enxertos ósseos: características de alguns materiais. Revista ABO Nacional, 2008, 16( $3)$.

17. Zago, MA.; Covas, DT. Células-tronco: Origens e Propriedades. In: Células-tronco: A nova Fronteira da medicina. Ed. M. Zago e D. T. Covas, pp. 3-20. Editora Atheneu São Paulo, 2006.

18. Maiorana C, Sommariva L, Brivio P, Sigurtà D, Santoro F. Maxillary sinus augmentation with anorganic bovine bone (Bio-Oss) and autologous platelet-rich plasma: preliminary clinical and histologic evaluations. Int $\mathrm{J}$ Periodontics Restorative Dent 2003 Jun;23 (3) : 227-235.

19. Mazzoneto, R. Reconstruções em Implantodontia - Protocolos clínicos para o sucesso e aprevisibilidade. Ed. Napoleão, 2009, 1'Edição. Nova Odessa - SP, Brasil.

20. Aubin J. E.; Liu F. The osteoblast lineage. In: Bilizekian, J., Raisz, L., and Rodan, G., editors. Principles of Bone Biology. San Diego, CA: Academic Press: 1996, 39-50.

21. Liu, Y.; Clark, RAF.; Huang, L.; Rafailovich, MH. Hyaluronic acid-gelatin fibrous scaffold produced by electrospinning of their aqueous solution for tissue engineering applications. In Advances inMaterial Design for Regenerative Medicine, Drug Delivery and Targeting/ Imaging 2010; 1140 :131-136.

22. Nardi N.B.; Meirelles S.L. Mesenchymal stem cells: isolation, in vitro expansion and characterization. HEP 2006; $174: 249-82$.

23. Locke M, Windsor J, Dunbar PR. Human adipose-derived stem cells: isolation, characterization and applications in surgery.ANZ J Surg, 2009, 79:235-244.

24. Vacanti, JP.; Langer, R. Tissue engineering: The design and fabrication of living replacement devices for surgical reconstruction and transplantation. Lancet, 1999; 354: 32-34.

25. Mesimäki K, Lindroos B, Törnwall J, Mauno J, Lindqvist C, Kontio R, Miettinen S, Suuronen R: Novel maxillary reconstruction with ectopic bone formation by GMP adipose stem cells.Int $J$ Oral MaxillofacSurg 2009, 38 :201-209. 
26. Chan, YL.; King, NM. Use of focused íon bean milling for investigating the mechanical properties of biological tissues: A study of human primary molars. Journal of the MechanicalBehavior of Biomedical Materials 2009,2 (4) : 375-383.

27. Fardin A.C., et al. Enxerto Ósseo em Odontologia: Revisão de Literatura. InnovImplant J, BiomaterEsthet, São Paulo, 2010, 5 (3): 48-52.

28. Zotarelli Filho IJ, Frascino LF, Greco OT, Araujo JDD, Bilaqui A, Kassis EN, Ardito RV andBonillaRodriguez GO. Chitosan-collagen scaffolds can regulate the biologicalactivities of adipose mesenchymal stem cells for tissueengineering. J Regen Med Tissue Eng. 2013; 2:12. http://dx.doi.org/10.7243/2050-1218-2-12.

29. Simonpieri, A., et al. (2012). Current Knowledge and Perspectives for the Use of Platelet-Rich Plasma (PRP) and Platelet-Rich Fibrin (PRF) in Oral and Maxillofacial Surgery Part 2: Bone Graft, Implant and Reconstructive Surgery Current Pharmaceutical Biotechnology, 13, pp. 1231-1256.

30. Tejero, R., Anitua, E. eOrive, G. (2014). Toward the biomimetic implant surface: Biopolymers on titaniumbased implants for bone regeneration. Journal of Progress in Polimeral Science, 39, pp. 1406-1447.

31. Carvalho PSP, Rosa AL, Bassi APF, Pereira LAVD. Biomateriais aplicados a implantodontia. Revista Implantnews2010;7 (3a-PBA):56-65.

32. Pereira IKC, Fernandes JRS, Melo ITS. Uso de membranas como barreiras protetoras de enxertos ósseos utilizados na implantodontia. Cadernode Ciências Biológicas e da Saúde. Boa Vista, n. 03, 2013.

33. Caballé-Serrano J, Sawada K, Schuldt Filho G, Bosshardt DD, Buser D, Gruber R. Bone Conditioned Medium: Preparation and Bioassay. J Vis Exp. 2015 Jul 8; (101):e52707.

34. Merli M, Merli I, Raffaelli E, Pagliaro U, Nastri L, Nieri M. Bone augmentation at implant dehiscences and fenestrations. A systematic review of randomised controlled trials. Eur J Oral Implantol. 2016 Spring;9(1):1132.

35. Moschouris P, Retzepi M, Petrie A, Donos N. Effect of Wnt3a delivery on early healing events during guided bone regeneration. Clin Oral Implants Res. 2016 Mar 27.

36. Caballé-Serrano J, Sawada K, Miron RJ, Bosshardt $\quad$ DD, Buser $\quad$ D, Gruber R. Collagen barrier membranes adsorb growth factors liberated from autogenous bone chips. Clin Oral Implants Res. 2016 Jan 28.

37. Saghiri MA, Asatourian A, Garcia-Godoy F, Sheibani N. The role of angiogenesis in implant dentistry part II: The effect of bone-grafting and barrier membrane materials on angiogenesis. Med Oral Patol Oral Cir Bucal. 2016 Mar 31:0.

38. Fujioka-Kobayashi M, Sawada K, Kobayashi E, Schaller B, Zhang Y, Miron RJ.Recombinant Human Bone Morphogenetic Protein 9 (rhBMP9) Induced Osteoblastic Behaviour on a Collagen Membrane Compared With rhBMP2. J Periodontol. 2016 Jan 11:1-14.

39. Dai Z, Shu Y, Wan C, Wu C. Effects of $\mathrm{pH}$ and thermally sensitive hybrid gels on osteogenic differentiation of mesenchymal stem cells. J Biomater Appl. 2015;29:1272-83. 